\title{
rpoB-PCR amplified gene and temporal temperature gradient gel electrophoresis: a rapid tool to analyse bacterial strains representative of cold-smoked salmon microflora
}

\author{
S. Giacomazzi ${ }^{1}$, F. Leroi ${ }^{1}$, C. L'Henaff ${ }^{2}$ and J.-J. Joffraud ${ }^{1}$
}

${ }^{1}$ Laboratoire de Génie Alimentaire, IFREMER, Rue de l'île d'Yeu, BP 21105, 44311 Nantes cedex 3, France ;

${ }^{2}$ ENITIAA, Rue de la géraudière, BP 82225, 44322 Nantes cedex 3, France

\begin{abstract}
Aim: To evaluate $r p o B$ gene as a biomarker of microbial biodiversity associated to cold-smoked salmon by a novel nested-polymerase chain reaction/temporal temperature gradient gel electrophoresis (PCR/TTGE) technique applied on pure cultures of reference strains.
\end{abstract}

Methods and Results: DNA obtained from pure cultures of reference strains was used in a succession of a first PCR amplification of $r p o B$ fragment with degenerated nonclamped primers and a nested-PCR with nondegenerated clamped primers. PCR products were then applied on a TTGE gel in order to analyse strains profile. High quantity of nested-PCR products were obtained for each tested strain and TTGE profiles showed a good separation between the different reference bacteria and an easy way to associate one band to one species.

Conclusion: The nested-PCR/TTGE technique used in this study is a promising way of investigating bacterial community structure of cold-smoked salmon or other food matrix.

Significance and Impact of the Study: Because of its single copy state leading to single band profiles in TTGE, rpoB constitute a good potential molecular marker for further development of coldsmoked salmon biodiversity analysis. 


\section{Introduction}

Cold-smoked salmon is a lightly-preserved fish product which may suffer from spoilage. Spoilage effects are usually the result of bacterial proliferation. In recent years some studies have considered the specific bacterial flora of cold-smoked salmon and determined the main taxonomic groups associated to the spoiling flavours (Leroi et al. 1998 ; Paludan-Müller et al. 1998 ; Truelstrup Hansen et al. 1998 ; Stohr et al. 2001). The biodiversity of cold-smoked salmon microflora is complex and varies with the factory considered (Leroi et al. 2001). Many marine Gram negative bacteria, such as Photobacterium phosphoreum, Shewanella putrefaciens, Vibrio spp, as well as Enterobacteriaceae can be present. During the vacuum storage, Lactic Acid Bacteria (LAB)(Carnobacterium piscicola, C. divergens, Lactobacillus curvatus, L. sakei ...) as well as Brochothrix thermosphacta and in some cases yeasts may become dominant (Jorgensen and Huss 1989 ; Truelstrup Hansen 1995 ; Paludan-Müller et al. 1998). Knowledge of community structure evolution during storage is important to allow a better understanding of mechanisms involved in spoilage and to master the quality of the product. Microbial cultivation techniques are generally used to investigate microbial diversity in such products. However evaluation of bacterial community evolution using only cultivation techniques have proved its limits. Those are time consuming and culture media used, temperature and oxygen contents create selections that may not accurately reflect the microorganisms really present in the product. Thus, Carnobacterium spp., a dominant bacteria in cold-smoked salmon (Truelstrup Hansen 1995 ; Leroi et al. 1998), has been underestimated until 1995 because of its inhibition by sodium acetate contained in Mann Rogosa and Sharpe (De Man et al. 1960) culture medium.

Therefore, alternate molecular methods such as TTGE, DGGE (Denaturing Gradient Gel Electrophoresis), SSCP (Single Strand Conformation Polymorphism) (Giraffa and Neviani 2001) have proved their efficiency to study bacterial community structure and its evolution in 
various environments and products (Amann 1995 ; Cocolin et al. 2000 ; Niemi et al. 2001 ; Vasquez et al. 2001 ; Ogier et al. 2002). Application of molecular methods to cold-smoked salmon was only reported by Cambon-Bonavita (2001) who used an ARDRA (Amplified Ribosomal DNA Restriction Analysis) technique to evaluate the microbial diversity of sliced vacuum-packed cold-smoked salmon.

Community analysis of bacteria using molecular methods is commonly performed by PCR amplification of the 16S rDNA gene. But as it was reviewed by Fogel et al.(1999), several bands per species could be seen in a high resolution PCR-DGGE analysis due to heterogeneity of $16 \mathrm{~S}$ rDNA. As a solution, $r p o B$ gene has been described as a suitable gene for PCR-DGGE or TTGE (Dahllöf et al. 2000) since only one band per species was observed and banding pattern from a mixture of bacteria could clearly be related to single isolates.

Here we report a preliminary study where a combination of a rpoB Nested-PCR amplification and TTGE technique was evaluated to differentiate bacterial reference strains, from international culture collection, representative of the main genus or species composing coldsmoked salmon microflora. Method was then applied to strains previously isolated from coldsmoked salmon. 


\section{Materials and Methods}

\section{Strains and media}

Brochothrix thermosphacta CIP 103251 T and SF 680, Carnobacterium piscicola CIP 103158T and SF668, Lactobacillus alimentarius CIP 102986T and SF762, L. farciminis CIP 103136T and SF812, L. sakei subsp sakei CIP 103139T and SF842, Photobacterium phosphoreum CIP 102511T and SF674, Serratia proteamaculans CIP 52.56 and SF1460, Shewanella putrefaciens CIP 80.40T and SF672 were obtained from the Collection de l'Institut Pasteur, France (CIP) and from IFREMER collection (SF). Strains from IFREMER collection have been isolated and identified by Leroi et al. (1998). All strains were revived from frozen storage $\left(-80^{\circ} \mathrm{C}\right)$ and grown in Brain Heart Infusion (BHI) at $20^{\circ} \mathrm{C}$ except $P$. Phosphoreum at $15^{\circ} \mathrm{C}$ and Lactobacillus strains in Man Rogosa Sharp (MRS) at $20^{\circ} \mathrm{C}$. MRS and BHI came from Biokar Diagnostic Beauvais, France.

\section{Extraction of bacterial DNA}

$5 \mathrm{ml}$ of the bacterial suspension was centrifuged (15 min, $10000 \mathrm{~g}$ ). The pellet was washed twice with $1 \mathrm{X}$ TE buffer (Tris $10 \mathrm{mM}$, EDTA $1 \mathrm{mmol} \mathrm{l}^{-1}$ ) before being incubated $\left(2 \mathrm{~h} ; 37^{\circ} \mathrm{C}\right)$ in $2 \mathrm{ml}$ of a lysosyme $\left(2 \mathrm{mg} \mathrm{ml}^{-1}\right)$-Tween80 (0.1\%) solution. $2 \mathrm{ml}$ of a proteinase $\mathrm{K}$ (Qiagen, Courtaboeuf, France)(100 $\left.\mu \mathrm{g} \mathrm{ml}^{-1}\right)$-SDS (1 \%) solution was added before incubation (2 h ; $55^{\circ} \mathrm{C}$ ). The phenol extraction and ethanol precipitation method from Ausubel et al. (2002) was performed to purify bacterial DNA.

\section{PCR amplification}

Degenerated primers rpoB_1675 and rpoB_2063 (Giacomazzi 2002; Gravelat 2002) were used in the first PCR. Optimal non degenerated primer rpoB_1675 ndg and rpoB_2063ndg (Giacomazzi 2002; Gravelat 2002) were used for a Nested-PCR. A GC clamp (Dahllöf et al. 2000) was added to the rpoB_1675ndg primer. 
The PCR mixture (25 $\mu \mathrm{l})$ contained as final concentrations : $200 \mu \mathrm{mol} \mathrm{l}^{-1}$ of desoxynucleotide triphosphate mix (Eppendorf, Le Pecq, France), 1 X TaqMaster buffer, $1 \mathrm{X}$ Taq buffer with $\mathrm{MgCl}_{2}\left(1.5 \mathrm{mmol}{ }^{-1} \mathrm{Mg}^{2+}\right), 0.5 \mathrm{U}$ of MasterTAQ polymerase (Eppendorf, France), $0.2 \mu \mathrm{mol} \mathrm{l}^{-1}$ each primer $r p o B$ dg or ndg and 50 ng of template DNA (estimated by OD at $260 \mathrm{~nm}$ ). PCR amplification was performed on PCRsprint thermocycler (Hybaid, Middlesex, UK). The first PCR was performed using the following protocol: initial denaturation $\left(1 \mathrm{~min}, 94^{\circ} \mathrm{C}\right)$, followed by 20 cycles of denaturation $\left(94^{\circ} \mathrm{C}\right.$ for $\left.20 \mathrm{~s}\right)$, primer annealing $\left(58.5^{\circ} \mathrm{C}\right.$ for $\left.30 \mathrm{~s}\right)$ and extension $\left(72^{\circ} \mathrm{C}\right.$ for $45 \mathrm{~s}$ ). A final extension at $72^{\circ} \mathrm{C}$ for 10 min was performed. $1 \mu \mathrm{l}$ of amplicon were used as matrix for the Nested-PCR which was performed under identical conditions as described above except for primers (use of clamped non degenerated primers), and for number of cycles (30 cycles). The size and the amount of amplified DNA were verified by electrophoresis on $1 \%(\mathrm{w} / \mathrm{v})$ agarose gel (Eurogentec, Seraing, Belgium) containing ethidium bromide Gel was photographed by the image viewer ImageMaster VDS-CL (Amersham Pharmacia Biotech, Orsay, France).

\section{TTGE analysis}

20 to $40 \mu \mathrm{l}$ of Nested-PCR products (approximately $200 \mathrm{ng}$ ) were loaded onto a 6\% polyacrylamide gel prepared from 40\% [wt/vol] acrylamide -N, N'-methylenebisacrylamide stock, 37.5:1 (Bio-rad Laboratories, Marnes la Coquette, France) containing 6M urea in 1.25 X TAE (50 X TAE stock solution, Bio-Rad Laboratories) and $20 \%$ formamide (Bio-Rad Laboratories). TTGE was performed on a DCode Universal Mutation Detection System (BioRad Laboratories) for $15 \mathrm{~h}$ at $80 \mathrm{~V}$ in $1.25 \mathrm{X}$ TAE buffer. Gel system temperature was programmed to gradually increase by $0.5^{\circ} \mathrm{C} / \mathrm{h}$ from $46^{\circ} \mathrm{C}$ to $53^{\circ} \mathrm{C}$. DNA was stained with a mixture of SYBR Green I and II (v/v) (Sigma- Aldrich, France). Gel was observed and photographed by the image viewer ImageMaster VDS-CL. 


\section{Results}

Amplification of $r p o B$ gene using a Nested-PCR amplification by two different sets of primers led to the amplification of a 418 bp PCR product. All the pure reference strains tested in our study showed a good amplification of the rpoB fragment (Figure 1). An important quantity of amplicon (around $60 \mathrm{ng}^{-1} \mathrm{l}^{-1}$ ) estimated by DNA ladder comparison on agarose gel was obtained.

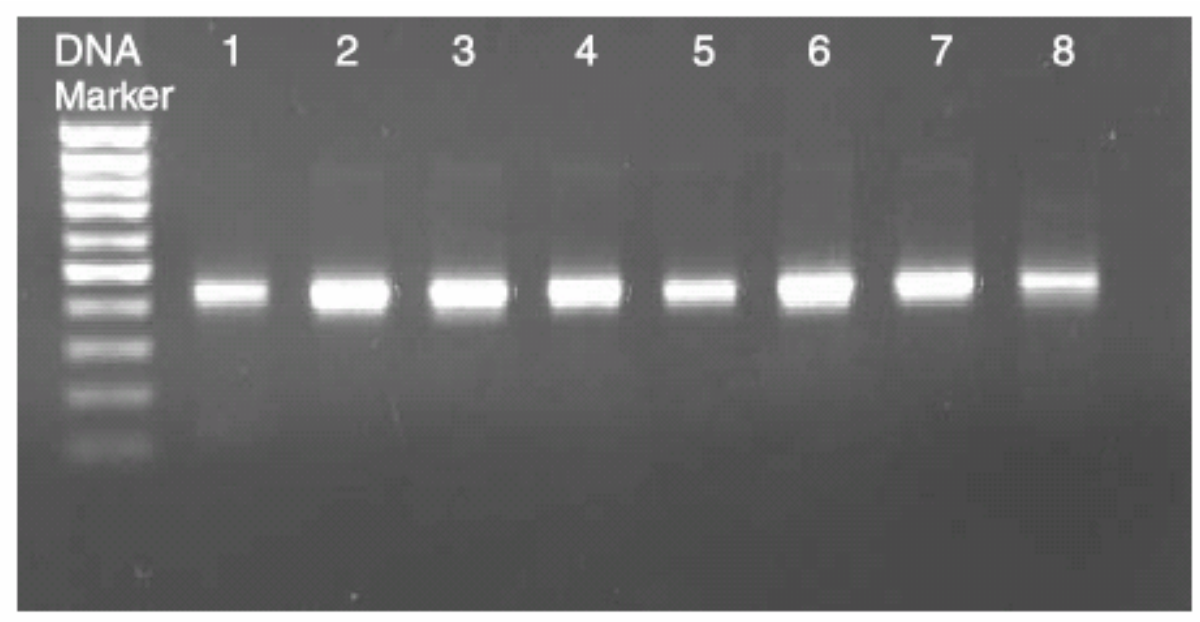

Figure 1 : Agarose gel electrophoresis of the rpoB amplified products (5 $\mu \mathrm{l})$ obtains for the reference strains. 1 : Lactobacillus alimentarius, 2: Lactobacillus farciminis, 3: Lactobacillus sakei, 4: Brochothrix thermosphacta, 5: Carnobacterium piscicola, 6: Photobacterium phosphoreum, 7: Serratia proteomaculans, 8: Shewanella putrefasciens. Marker: $10 \mu$ l of Mass Ruler ${ }^{\mathrm{TM}}$ DNA ladder low range, MBI Fermentas, Lithuania).

Microflora of cold-smoked salmon is very complex including various genus and species. The temperature gradient domain of TTGE had to be high enough to separate strains phylogenetically very distant such as Gram positive and Gram negative. But the temperature ramp rate had to be slow enough to allow separation of very close strains such as $L A B$ and $B$. thermosphacta (whose rpoB DNA sequence have a very close melting temperature). Optimisation of TTGE parameters has required to test a lot of gradient domains and gel 
concentrations to overcome this constraint and to obtain differentiated profiles with reference strains (Figure 2). The same profiles were obtained with related strains previously isolated from cold-smoked salmon (profiles not shown). On the basis of the different migration in the TTGE gel it is possible to distinguish the different strains tested in this study. Gram positive bacteria are well separated from gram negative bacteria which showed a greater migration distance. All the strains belonging to LAB and $B$. thermosphacta are regrouped in the first part of the profile but could be discriminated from each other. This weak migration of Gram positive bacteria is in accordance with their high percentage of homology and implies on the basis of TTGE principle that $r p o B$ fragment sequences have a relative low GC content. Migration distance between these strains could be improved by reducing the temperature gradient domain but would lead to the lost of bands associated to Gram negative.

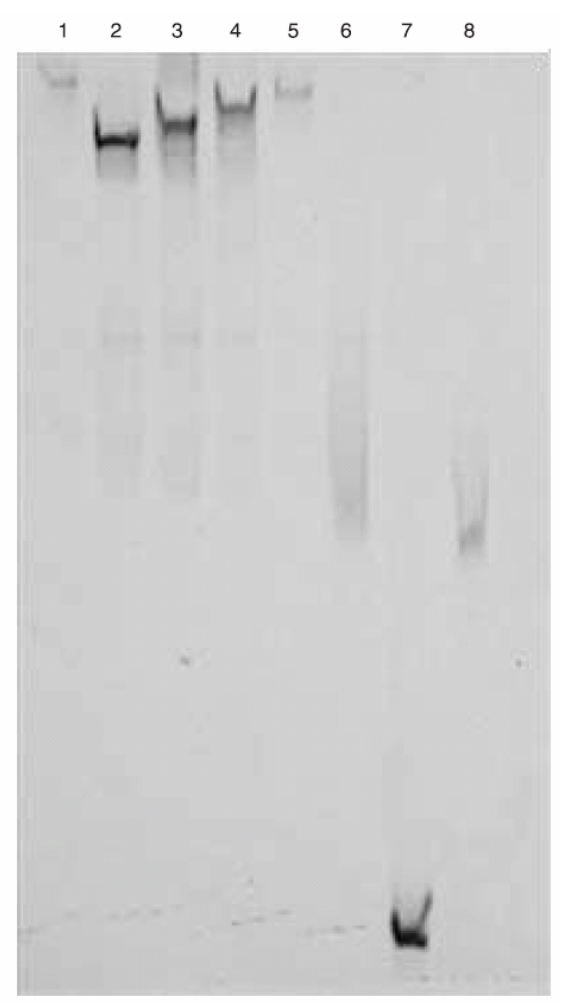

Figure 2 TTGE profiles performed on rpoB nested-PCR products on a 6\% AA, 7Murea, 20\% formamide gel; gradient: 46 to $53^{\circ} \mathrm{C}$; migration : 15 h at 80 volts in 1.25 TAE buffer. 1: Lactobacillus alimentarius, 2: Lactobacillus farciminis, 3: Lactobacillus sakei, 4: Brochothrix thermosphacta, 5: Carnobacterium piscicola, 6: Photobacterium phosphoreum, 7: Serratia proteomaculans, 8: Shewanella putrefasciens. 


\section{Discussion}

Previous studies have already demonstrated that polymorphism analysis of complex microbial communities, e.g. using DGGE, is more reproducible with rpoB gene than with $16 \mathrm{~S}$ rDNA (Dahllöf et al. 2000; Peixoto et al. 2002). Indeed, community structure studies suffer from the occurrence of a multiple copy state in 16S rDNA (Farrely et al. 1995). The number of 16s operons varies from species to species from one (Amikam et al. 1982) to more than 10 copies per cell (Jarvis et al. 1988; Young and Cole 1993). Moreover, sequence differences between copies of the 16S rDNA gene within a single species favour the occurrence of numerous heteroduplex molecules (Wang and Wang 1997). In contrast, $r p o B$ is always present as a single copy gene and thus does not suffer from such a discrepancy. However, until recently, $r p o B$ was still considered only as a complementary discriminator on the basis of amplification failure encountered with some strains (Dahllöf et al. 2000).

Giacomazzi 2002 and Gravelat 2002 have drawn new rpoB primers and successfully tested them on strains belonging to different phylogenetic groups such as Firmicutes, from Bacillus/Clostridium to Actinobacteria, and Proteobacteria from alpha to gamma subdivisions including strains with high GC\% offering a new convenient and specific tool for the study of bacterial phylogeny .

They also showed the interest to use Nested-PCR to add the GC clamp for TTGE application in a second step (Sheffield et al. 1989 ; Rosado et al. 1998). The presence of this GC-clamp was shown to hamper the direct PCR amplification of total bacterial DNA when this primer is used in a single step. To our knowledge, those primers had never been tested on bacterial species described in the present study or in a food matrix.

Comparison of TTGE profiles obtained from 16S rDNA amplification (Rachman et al. oral communication:http://www.clermont.inra.fr/internet/actualites/CBLAurilllac2003.htm-) with those of the present study with rpoB clearly showed different profiles for the same tested 
bacteria. With rpoB gene, a single band was obtained compared to 16S rDNA gene profiles which revealed multiple bands for pure strain. Our study supported the assertion of previous authors that rpoB is a better biomarker because of monocopy state (Dahllöf et al. 2000; Peixoto et al. 2002). Potentially, we could expect that in a bacterial community structure analysis of cold-smoked salmon, one band in TTGE profile would be associated to one specific species and that the main strains present in a bacterial community could be revealed by this rpoB Nested-PCR-TTGE method.

In conclusion, we showed that Nested-PCR/ TTGE technique is a promising way of investigating bacterial community structure of cold-smoked salmon. Further development considering bacterial DNA extraction efficiency from artificially contaminated and naturally contaminated cold-smoked salmon using Nested-PCR/TTGE technique on $r p o B$ gene has to be undertaken to validate this specific and rapid method of distinction of bacterial community structure in a food matrix.

\section{Acknowledgement}

Thanks to F. Loisy for improvement of English language. 


\section{References}

Amann, R.I. (1995) In situ identification of micro-organisms by whole cell hybridization with rRNA-targeted nucleic acid probes. In Molecular Microbial Ecology Manual. 115. Kluver Academic Publishers.

Amikam, D., Razin, S. and Glaser, G. (1982) Ribosomal RNA genes in Mycoplasma. Nucleic Acids Research 10 (14):4215-4222.

Ausubel, F.M., Brent, R., Kingston, R.E., Moore, D.D., Seidman, J.G., Smith, J.A. and Struhl, K. (ed.) (2002). Current Protocols in Molecular Biology. Vol. 1. New York: John Wiley and Sons.

Cambon-Bonavita, M.A., Lesongeur, F., Menoux, S., Lebourg, A. and Barbier, G. (2001) Microbial diversity in smoked salmon examined by a culture-independent molecular approach - a preliminary study. International Journal of Food Microbiology 70, 179187.

Cocolin, L., Manzano, M., Cantoni, C. and Comi, G. (2000) Development of a rapid method for the identification of Lactobacillus spp. isolated from naturally fermented italian sausages using a polymerase chain reaction-temperature gradient gel electophoresis. Letters in Applied Microbiology 30 126-129.

Dahllöf, I., Baillie, H. and Kjelleberg, S. (2000) rpoB-based microbial community analysis avoids limitations inherent in 16S rRNA gene intraspecies heterogeneity. Applied and Environmental Microbiology 66, 3376-3380.

De Man, J.C., Rogosa, M. and Sharpe, M.E. (1960) A medium for the cultivation of Lactobacilli. Journal of Applied Bacteriology 23, 130-135.

Farrely, V., Rainey, F.A. and Stackebrandt, E. (1995) Effect of genome size and rrn gene 
copy number on PCR amplification of 16S rRNA genes from a mixture of bacterial species. Applied and Environmental Microbiology 61 (7):2798-2801.

Fogel, G.B., Collins, C.R., Li, J. and Brunk, C.F. (1999) Prokaryotic genome size and SSU rDNA copy number:estimation of microbial relative abundance from a mixed population. Microbial Ecology 38, 93-113.

Giacomazzi, S. (2002) Mise au point et validation de techniques d'évaluation des communautés microbiennes dans les milieux complexes de type sols. PhD Thesis. Université de Technologie de Compiègne, Compiègne, France

Giraffa, G. and Neviani, E. (2001) DNA-based, culture-independent strategies for evaluating microbial communities in food-associated ecosystems. International Journal of Food Microbiology 67, 19-34.

Gravelat, F. N. (2002) Mise en oeuvre de processus bactériens de déshalogénation et de dégradation des polychlorobiphényles pour la bioremédiation d'un sol pollué. Utilisation du polymorphisme des gènes $r p o B$ et bphC pour le suivi des souches bactériennes dans le sol. PhD Thesis. Université de Technologie de Compiègne, Compiègne, France .

Jarvis, E.D., Widom, R.L., LaFauci, G., Setoguchi, Y., Richter, I.R. and Rudner, R. (1988) Chromosomal organization of rRNA operons in Bacillus subtilis. Genetics 120 (3):625-635.

Jorgensen, B.R. and Huss, H.H. (1989) Growth and activity of Shewanella putrefaciens isolated from spoiling fish. International Journal of Food Microbiology 9, 51-62.

Leroi, F., Joffraud, J.J., Chevalier, F. and Cardinal, M. (1998) Study of the microbial ecology 
of cold smocked salmon during storage at $8^{\circ} \mathrm{C}$. International Journal of Food Microbiology 39, 111-121.

Leroi, F., Joffraud, J.J., Chevalier, F. and Cardinal, M. (2001) Research of quality indices for cold-smoked salmon using a stepwise multiple regression of microbiological counts and physio-chemical parameters. Journal of Applied Microbiology 90 578-587.

Niemi, R.M., Heiskanen, I., Wallenius, K. and Lindström, K. (2001) Extraction and purification of DNA in rhizosphere soil samples for PCR-DGGE analysis of bacterial consortia. Journal of Microbiological Methods 45, 155-165.

Ogier, J.-C., Son, O., Gruss, A., Tailliez, P. and Delacroix-Buchet, A. (2002) Identification of the bacterial microflora in dairy products by Temporal Temperature Gradient Gel Electrophoresis. Applied and Environmental Microbiology 68, 3691-3701.

Paludan-Müller, C., Dalgaard, P., Huss, H.H. and Gram, L. (1998) Evaluation of the role of Carnobacterium piscicola in spoilage of vacuum and modified atmosphere-packedsmoked salmon stored at $5^{\circ} \mathrm{C}$. International Journal of Food Microbiology 39, 155 166.

Peixoto, R.S., da Costa Coutinho, H.L., Rumjanek, N.G., Macrae, A. and Rosado, A.S. (2002) Use of rpoB and 16SrRNA genes to analyse bacterial diversity of a tropical soil using PCR and DGGE. Letters in Applied Microbiology 32, 316-320.(Abstract)

Rosado, A.S., Duarte, G.F., Seldin, L. and Van Elsas, J.D. (1998) Genetic diversity of nifH gene sequences in Paenibacillus azotofixans strains and soil samples analysed by Denaturing Gradient Gel Electrophoresis of PCR-amplified gene fragments. Applied and Environmental Microbiology 64, 2770-2779.(Abstract) 
Sheffield, V.C., Cox, D.R., Lerman, L.S. and RM., N. (1989) Attachment of a 40-base-pair G+C-rich sequence(GC clamp) to genomic DNA fragments by the polymerase chain reaction results in improved detection of single-base changes. Proceeding of National Acadademic Sciences USA 86 (1):232-236.

Stohr, V., Joffraud, J.J., Cardinal, M. and Leroi, F. (2001) Spoilage potential and sensory profile associated with bacteria isolated from cold smoked salmon. Food Research International 34 797-806.

Truelstrup Hansen L. (1995) Quality of chilled vacuum-packed cold-smoked salmon. Ph.D. Thesis. Danish Institute for Fisheries Research and The Royal Veterinary and Agricultural University of Copenhagen, Denmark.

Truelstrup Hansen, L., Drewes Ronved, S. and Huss, H.H. (1998) Microbiological quality and shelf life of cold-smoked salmon from three different processing plants. Food Microbiology 15, 137-150.

Vasquez, A., Ahrné, S., Pettersson, B. and Molin, G. (2001) Temporal temperature gradient n gel electrophoresis (TTGE) as a tool for identification of Lactobacillus casei, Lactobacillus paracasei, Lactobacillus zeae and Lactobacillus rhamnosus. Letters in Applied Microbiology 32, 215-219.(Abstract)

Wang, G.C. and Wang, Y. (1997) Frequency of formation of chimeric molecules as a consequence of PCR coamplification of 16S rRNA genes from mixed bacterial genomes. Applied and Environmental Microbiology 63 (12):4645-4650.

Young, M. and Cole, S.T. (1993) Clostridium. In Bacillus subtilis and other gram-positive organisms. A.L. Sonenshein, J.A.H. and R. Losick. : 35-52.American Society for Microbiology, Washington, D.C. 